\title{
Reconstruction of Ankle and Heel Defects with Peroneal Artery Perforator-Based Pedicled Flaps
}

\author{
Deok Ki Ahn' ${ }^{1}$ Dae Hyun Lew ${ }^{1}$, Tai Suk Roh ${ }^{2}$, Won Jai Lee ${ }^{1}$ \\ ${ }^{I}$ Department of Plastic and Reconstructive Surgery, Yonsei University Health System, Severance Hospital, Yonsei University College of \\ Medicine, Seoul; ${ }^{2}$ Department of Plastic and Reconstructive Surgery, Gangnam Severance Hospital, Yonsei University College of Medicine, \\ Seoul, Korea
}

Background The reconstruction of ankle and heel defects remains a significant problem for plastic surgeons. The following options exist for reconstructing such defects: local random flaps, reverse flow island flaps, and free flaps. However, each of these methods has certain drawbacks. Peroneal artery perforators have many advantages; in particular, they are predictable and reliable for ankle and heel reconstructions. In this study, we report our clinical experience with peroneal artery perforator-based pedicled flaps in ankle and heel reconstructions. Methods From July 2005 to October 2012, 12 patients underwent the reconstruction of soft tissue defects in the ankle and heel using a peroneal artery perforator-based pedicled flap. These 12 cases were classified according to the anatomical area involved. The cause of the wound, comorbidities, flap size, operative results, and complications were analyzed through retrospective chart review.

Results The mean age of the patients was 52.4 years. The size of the flaps ranged from $5 \times 4$ to $20 \times 8 \mathrm{~cm}^{2}$. The defects were classified into two groups based on whether they occurred in the Achilles tendon $(n=9)$ or heel pad $(n=3)$. In all 12 patients, complete flap survival was achieved without significant complications; however, two patients experienced minor wound dehiscence. Nevertheless, these wounds healed in response to subsequent debridement and conservative management. No patient had any functional deficits of the lower extremities. Conclusions Peroneal artery perforator-based pedicled flaps were found to be a useful option for the reconstruction of soft tissue defects of the ankle and heel.

Keywords Lower extremity / Perforator flap / Achilles tendon / Heel
Correspondence: Won Jai Lee Department of Plastic and Reconstructive Surgery, Yonsei University Health System, Severance Hospital, Yonsei University College of Medicine, 250 Seongsan-ro, Seodaemun-gu, Seoul 03722, Korea Tel: +82-2-2228-2215

Fax: +82-2-393-6947

E-mail: pswjlee@yuhs.ac

Received: 23 Mar 2015 • Revised: 20 Jun $2015 \bullet$ Accepted: 22 Jun 2015

pISSN: 2234-6163 • elSSN: 2234-6171 • http://dx.doi.org/10.5999/aps.2015.42.5.619 • Arch Plast Surg 2015;42:619-625

No potential conflict of interest relevant to this article was reported.

\section{INTRODUCTION}

The reconstruction of ankle and heel defects remains a significant problem for plastic surgeons, especially in patients with underlying vascular disease, which can induce circulation problems, and in patients with chronic wounds induced by severe trauma. Various options have been reported in the literature for the cov- erage of soft tissue defects of the ankle and heel [1-3]. Utilizing local flaps with random vascularity can provide a simple way to cover soft tissue defects; however, this technique is restricted by the limited amount of tissue that can be moved from the donor site to the defect area [4]. Distally-based sural neurocutaneous flaps have also been used for ankle and heel pad reconstruction. Due to the development of the pedicle dissection, more flexibili- 
ty of flap rotation and reduced donor site deformity were obtained. This flap has become one of the most common choices in ankle and heel pad reconstruction [5-8]. The use of free flaps can provide well-vascularized tissue of any size distant from the zone of injury. Such a method usually requires a single-stage procedure and is associated with a reduced infection rate due to high vascularity [9]. Additionally, free flaps can be performed without considering the position of the pedicle artery perforator. However, such flaps also have disadvantages, including long periods of anesthetic use, donor-site morbidity, the potential lack of available recipient vessels, and the need for highly specific skill sets and clinical back-up [2].

The peroneal artery perforator-based pedicled flap was originally introduced by Koshima et al. [10] in Japan in 1992. It was introduced as an alternative to distally-based sural neurocutaneous flaps in ankle and heel reconstructions [3,10-12]. The anatomy of the peroneal artery perforator has been widely researched and found to be primarily useful for the reconstruction of ankle and heel defects. These perforators allow a flexible surgical design, with excellent applicability and reduced donor-site morbidity. Peroneal artery perforator-based pedicled flaps are one of the most effective choices for ankle and heel defects $[12,13]$.

In this study, we describe the surgical technique of using peroneal artery perforator-based pedicled flaps and present the results of our retrospective analysis regarding the location of the defect area and the type and size of the flap. Moreover, we used retromalleolar cutaneous perforators arising from the most distal part of the peroneal artery in the lateral retromalleolar space in order to lower the pivot point. We can lower the pivot point by up to $1-3 \mathrm{~cm}$ above the tip of the lateral malleolus, leading to a shorter pedicle length and lower donor-site morbidity.

\section{METHODS}

A retrospective analysis was performed using the medical records of 12 patients who underwent heel and ankle reconstruction at the author's medical center between 2005 and 2012. For each patient, the following data were collected and recorded: sex, age, body mass index, etiology, comorbidities, the size of the defect, the area of the defect, the size of the flap, the results of the operation, and complications. The areas of the defects were classified as the Achilles tendon or heel pad. We used propeller flaps and peninsular flaps for the coverage of ankle and heel defects. Propeller flaps were used more frequently, as they allowed more flexibility in insetting and also had the advantage of greater versatility. The pivot could be applied to a soft tissue defect in any direction, up to 180 degrees. We preferred to use propeller flaps rather than peninsular flaps when a large arc of rotation was needed. Although the peninsular flap has a smaller rotation arc than the propeller flap, it has the advantage of involving a lower risk of venous congestion.

\section{Surgical techniques}

A line was drawn from the mid-popliteal point to the midpoint between the Achilles tendon and the lateral malleolus. The peroneal perforator vessels were mapped using a portable Doppler ultrasound probe in this area the day before the operation. The size of the soft-tissue defect was measured after surgical debridement was performed. The flap was designed along the direction of the peroneal artery, with the first incision made along the anterior border of the designed flap. The dissection proceeded posteriorly in the suprafascial plane, and previously confirmed perforators that appeared on ultrasound imaging were identified. Of the perforators that were identified, we chose the perforator with the largest diameter. When we operated on defects of the Achilles tendon and heel pad, we chose the most distal perforator for lowering the pivot point of the flap. When the perforator was dissected properly, a posterior incision was made, and complete undermining was performed. Retrograde intramuscular or intraseptal dissection of the selected perforator increased the length of the perforator, contributing to a greater degree of rotation arc, less tension, and longer reach. After the raw surface was covered with the elevated flap, the flap was sutured with 3-0 and 4-0 vicryl sutures, and the donor site was repaired primarily with a split-thickness skin graft. A drain was placed subcutaneously and removed when the amount of drainage was sufficiently reduced. A leg splint was applied, and strict elevation of the flap was required for one to two weeks postoperatively.

\section{RESULTS}

The mean age of the patients was 52.4 years (range, 18-76 years). The average body mass index was $21.4 \mathrm{~kg} / \mathrm{m}^{2}$. The defects ranged in size from $3 \times 4$ to $14 \times 10 \mathrm{~cm}^{2}$. The flaps ranged in size from $5 \times 4$ to $20 \times 8 \mathrm{~cm}^{2}$. The average follow-up period was 9.7 months. The cause of the soft-tissue defect was trauma in four patients, pressure ulcers in six patients, and single cases of tendinous xanthoma and Achilles tendinitis. Some patients also had one or more of the following comorbidities: hypertension, diabetes, end-stage renal disease, coronary artery occlusive disease, and peripheral artery occlusive disease. Detailed information about these patients is presented in Table 1.

A total of 12 patients were included in this study. In the nine patients with Achilles tendon defects, reconstructions were performed using eight propeller flaps and one peninsular flap. All three patients with heel pad defects were treated with propeller 
Table 1. Patient demographics and clinical information

\begin{tabular}{|c|c|c|c|c|c|c|c|c|c|c|c|c|c|c|}
\hline $\begin{array}{l}\text { Patient } \\
\text { number }\end{array}$ & $\begin{array}{l}\text { Sex/ } \\
\text { Age } \\
\text { (yr) }\end{array}$ & $\begin{array}{l}\text { BMI } \\
(\mathrm{kg} / \\
\left.\mathrm{m}^{2}\right)\end{array}$ & Etiology & Comorbidities & $\begin{array}{l}\text { Defect } \\
\text { area }\end{array}$ & $\begin{array}{c}\text { Defect } \\
\text { size } \\
(\mathrm{cm})\end{array}$ & $\begin{array}{l}\text { Type of } \\
\text { flap }\end{array}$ & $\begin{array}{l}\text { Flap } \\
\text { size } \\
(\mathrm{cm})\end{array}$ & $\begin{array}{l}\text { Type of } \\
\text { pedicle }\end{array}$ & $\begin{array}{l}\text { Distance } \\
\text { from the } \\
\text { tip of the } \\
\text { lateral } \\
\text { malleolus } \\
(\mathrm{cm})\end{array}$ & $\begin{array}{l}\text { Pedicle } \\
\text { length } \\
(\mathrm{cm})\end{array}$ & $\begin{array}{l}\text { Follow- } \\
\text { up } \\
(\mathrm{mo})\end{array}$ & Result & Complications \\
\hline 1 & $\begin{array}{c}\text { Female/ } \\
72\end{array}$ & 25.5 & Crush & CAOD & $\begin{array}{c}\text { Achilles } \\
\text { area }\end{array}$ & $9 \times 8$ & Peninsular & $10 \times 9$ & Septocutaneous & 2 & 1.1 & 11 & $\begin{array}{c}\text { Complete } \\
\text { healing }\end{array}$ & - \\
\hline 2 & $\begin{array}{c}\text { Female/ } \\
35\end{array}$ & 23.2 & Crush & - & $\begin{array}{c}\text { Achilles } \\
\text { area }\end{array}$ & $14 \times 10$ & Propeller & $14 \times 10$ & Septocutaneous & 3 & 1.4 & 13 & $\begin{array}{c}\text { Complete } \\
\text { healing }\end{array}$ & - \\
\hline 3 & $\begin{array}{c}\text { Male/ } \\
26\end{array}$ & 20.8 & $\begin{array}{l}\text { Tendinous } \\
\text { xanthoma }\end{array}$ & - & $\begin{array}{c}\text { Achilles } \\
\text { area }\end{array}$ & $12 \times 5$ & Propeller & $20 \times 8$ & Septocutaneous & 1 & 1.6 & 5 & $\begin{array}{c}\text { Complete } \\
\text { healing }\end{array}$ & - \\
\hline 4 & $\begin{array}{l}\text { Male/ } \\
55\end{array}$ & 20.3 & $\begin{array}{l}\text { Achilles } \\
\text { tendinitis }\end{array}$ & DM, HTN & $\begin{array}{c}\text { Achilles } \\
\text { area }\end{array}$ & $13 \times 6$ & Propeller & $15 \times 8$ & Septocutaneous & 1 & 1.2 & 10 & $\begin{array}{c}\text { Complete } \\
\text { healing }\end{array}$ & - \\
\hline 5 & $\begin{array}{l}\text { Male/ } \\
71\end{array}$ & 24 & Crush & DM, HTN & $\begin{array}{c}\text { Achilles } \\
\text { area }\end{array}$ & $6 \times 3$ & Propeller & $9 \times 3$ & Septocutaneous & 2,0 & $1.0,0.7$ & 22 & $\begin{array}{c}\text { Complete } \\
\text { healing }\end{array}$ & - \\
\hline 6 & $\begin{array}{l}\text { Male/ } \\
76\end{array}$ & 16.5 & $\begin{array}{l}\text { Pressure } \\
\text { sore }\end{array}$ & HTN & $\begin{array}{c}\text { Achilles } \\
\text { area }\end{array}$ & $4 \times 3$ & Propeller & $7 \times 4$ & Septocutaneous & 1 & 1.1 & 2 & $\begin{array}{c}\text { Complete } \\
\text { healing }\end{array}$ & - \\
\hline 7 & $\begin{array}{c}\text { Male/ } \\
18\end{array}$ & 21.9 & $\begin{array}{l}\text { Pressure } \\
\text { sore }\end{array}$ & - & $\begin{array}{c}\text { Achilles } \\
\text { area }\end{array}$ & $5 \times 3.5$ & Propeller & $5 \times 4$ & Septocutaneous & 1 & 1.5 & 6 & $\begin{array}{c}\text { Complete } \\
\text { healing }\end{array}$ & - \\
\hline 8 & $\begin{array}{l}\text { Male/ } \\
75\end{array}$ & 17.2 & $\begin{array}{l}\text { Pressure } \\
\text { sore }\end{array}$ & DM foot, ESRD & $\begin{array}{c}\text { Achilles } \\
\text { area }\end{array}$ & $4 \times 3.5$ & Propeller & $5 \times 4$ & Septocutaneous & 2 & 1.3 & 14 & $\begin{array}{c}\text { Complete } \\
\text { healing }\end{array}$ & $\begin{array}{l}\text { Minor wound } \\
\text { dehiscence }\end{array}$ \\
\hline 9 & $\begin{array}{l}\text { Male/ } \\
69\end{array}$ & 25 & Crush & HTN & $\begin{array}{c}\text { Achilles } \\
\text { area }\end{array}$ & $7 \times 3$ & Propeller & $7 \times 3$ & Septocutaneous & 1 & 1.1 & 5 & $\begin{array}{c}\text { Complete } \\
\text { healing }\end{array}$ & - \\
\hline 10 & $\begin{array}{l}\text { Male/ } \\
67\end{array}$ & 15.1 & $\begin{array}{l}\text { Pressure } \\
\text { sore }\end{array}$ & PAOD & $\begin{array}{l}\text { Heel } \\
\text { pad }\end{array}$ & $7 \times 4$ & Propeller & $9 \times 6$ & Septocutaneous & 2 & 1.0 & 10 & $\begin{array}{c}\text { Complete } \\
\text { healing }\end{array}$ & $\begin{array}{l}\text { Minor wound } \\
\text { dehiscence }\end{array}$ \\
\hline 11 & $\begin{array}{l}\text { Male/ } \\
23\end{array}$ & 28.7 & $\begin{array}{l}\text { Pressure } \\
\text { sore }\end{array}$ & - & $\begin{array}{l}\text { Heel } \\
\text { pad }\end{array}$ & $3 \times 4$ & Propeller & $4 \times 7$ & Septocutaneous & 3 & 1.1 & 13 & $\begin{array}{c}\text { Complete } \\
\text { healing }\end{array}$ & - \\
\hline 12 & $\begin{array}{l}\text { Male/ } \\
42\end{array}$ & 18.7 & $\begin{array}{l}\text { Pressure } \\
\text { sore }\end{array}$ & HTN & $\begin{array}{l}\text { Heel } \\
\text { pad }\end{array}$ & $5 \times 4$ & Propeller & $6 \times 4$ & Septocutaneous & 1 & 1.4 & 5 & $\begin{array}{c}\text { Complete } \\
\text { healing }\end{array}$ & - \\
\hline
\end{tabular}

BMI, body mass index; CAOD, coronary artery occlusive disease; DM, diabetes mellitus; HTN, hypertension; ESRD, end-stage renal disease; PAOD, peripheral artery occlusive disease.

flaps. In 10 patients, complete survival of the flaps was achieved without major complications; however, two patients experienced minor wound dehiscence.

\section{Case 1 (patient 7 , Achilles tendon defect, propeller flap)}

An 18-year-old man had a soft-tissue defect of the heel area, caused by a pressure sore (grade IV). Upon examination, a $5 \times 3.5 \mathrm{~cm}^{2}$ wound was found to be located in the vicinity of the Achilles tendon. A peroneal artery perforator-based pedicled flap measuring $5 \times 4 \mathrm{~cm}^{2}$ was elevated for coverage of the defect. The propeller flap was rotated 170 degrees to cover the defect. The donor site was repaired primarily. When the patient visited the outpatient clinic four months after the operation, the flap was well taken (Fig. 1).

\section{Case 2 (patient 5, Achilles tendon defect, propeller flap)}

A 71-year old male was involved in a car accident resulting in a chronic soft-tissue defect of the left lower leg. Upon examination, a $6 \times 3 \mathrm{~cm}^{2}$ wound was found to be located in the vicinity of the Achilles tendon. A peroneal artery perforator-based pedicled flap measuring $9 \times 3 \mathrm{~cm}^{2}$ was elevated for coverage of the defect. The propeller flap was rotated 80 degrees to cover the defect. The donor site was covered with a split-thickness skin graft (Fig. 2).

\section{Case 3 (patient 12, heel-pad defect, propeller flap)}

A 42-year-old man had a soft-tissue defect of the heel pad, caused by a pressure sore (grade IV). The size of the defect was $5 \times 4 \mathrm{~cm}^{2}$. A peroneal artery perforator-based pedicled flap measuring $6 \times 4 \mathrm{~cm}^{2}$ was elevated for coverage of the defect. The propeller flap was rotated 160 degrees to cover the defect. We chose a perforator that was sufficiently distant from the zone of injury. The donor site was covered with a split-thickness skin graft. When the patient visited the outpatient clinic five months after the operation, the flap and split-thickness skin graft were well taken (Fig. 3).

\section{DISCUSSION}

The reconstruction of soft tissue defects overlying the ankle and heel area remains a significant problem for plastic surgeons. Wound healing by secondary intention in this mobile area is significantly prolonged, leading to chronic, intractable wounds. Soft-tissue defects of the ankle and heel caused by diabetic ul- 


\section{Fig. 1. Case 1 (Achilles tendon defect, propeller flap)}

An 18-year-old man (patient 7) had a soft-tissue defect of the heel, caused by a pressure sore (grade IV). (A) On examination, a $5 \times 3.5 \mathrm{~cm}^{2}$ wound was found in the vicinity of the Achilles tendon. $(B, C)$ A peroneal artery perforator-based pedicled flap measuring $5 \times 4 \mathrm{~cm}^{2}$ was elevated for coverage of the defect. The propeller flap was rotated 170 degrees to cover the defect. The donor site was repaired primarily (black arrow, perforator).

(D) When the patient visited the outpatient clinic four months after the operation, the flap was well taken.
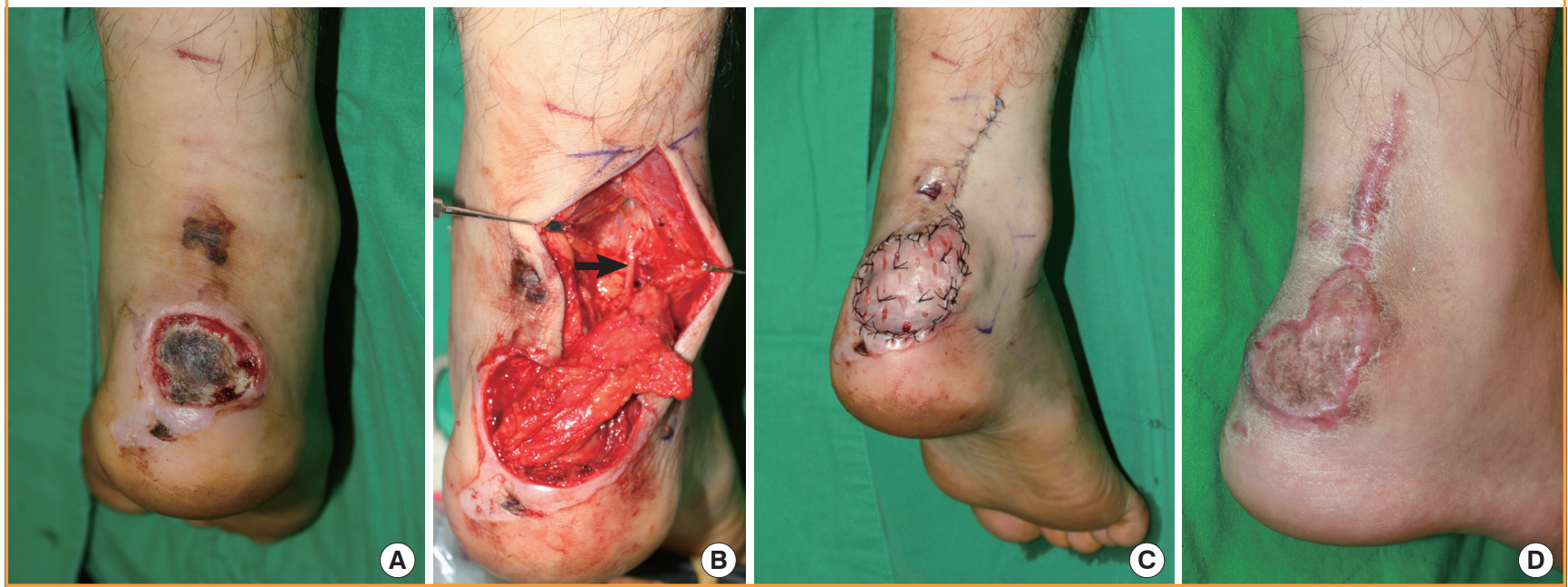

Fig. 2. Case 2 (Achilles tendon defect, propeller flap)

A 71-year-old male (patient 5) was involved in a car accident resulting in a chronic soft-tissue defect of the left lower leg. (A) On examination, a $6 \times 3 \mathrm{~cm}^{2}$ wound was found in the vicinity of the Achilles tendon. (B, C) A peroneal artery perforator-based pedicled flap measuring $9 \times 3 \mathrm{~cm}^{2}$ was elevated for coverage of the defect (black arrows, perforators). (D) The propeller flap was rotated 80 degrees to cover the defect. The donor site was covered with a split-thickness skin graft.
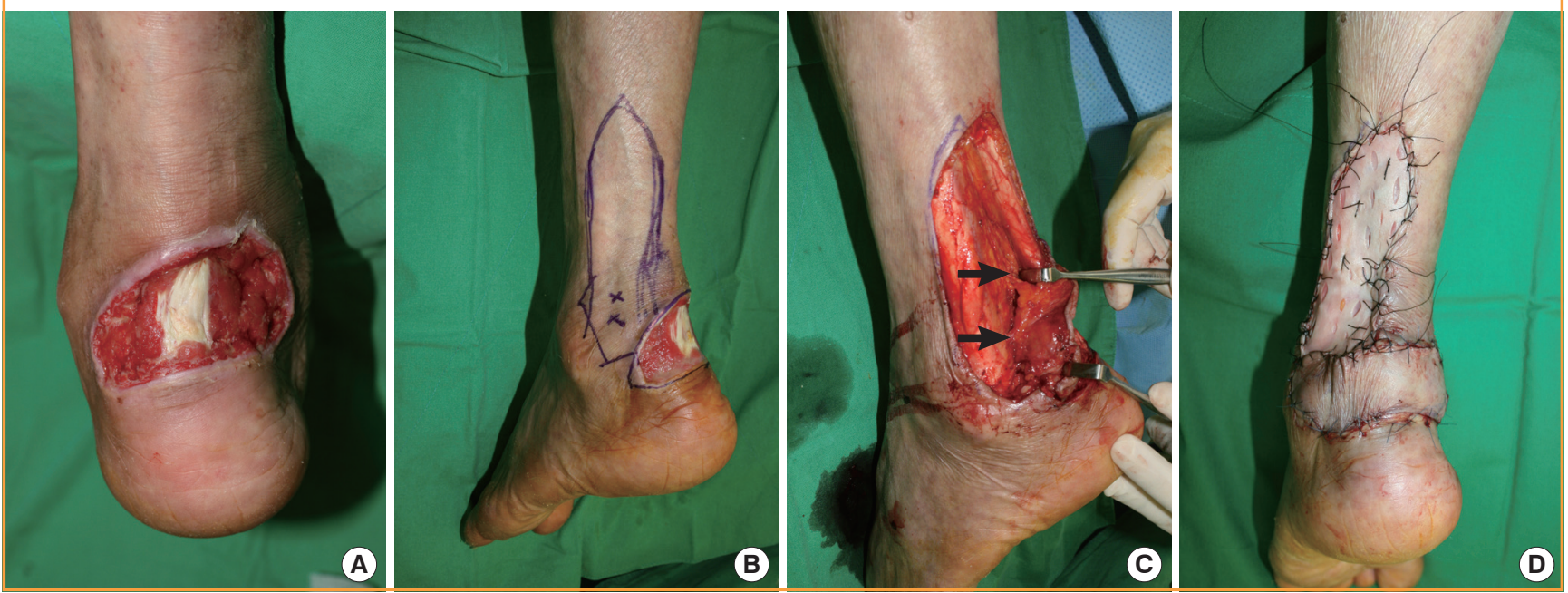

cers, trauma, burns, melanomas, pressure sores, or osteomyelitis cannot usually be covered with a simple skin graft. Skin grafting alone is indicated only in few cases due to an inhospitable recipient site, as secondary graft contracture will tether the tendon. In order to preserve the function of the Achilles tendon, soft tissue reconstruction must cushion the tendon while permitting gliding. Moreover, shoes can only be worn if the transferred tissue is not too bulky. In order to minimize unstable scar formation, the transferred tissue must resist shearing forces and pressure $[1,5,14-18]$.

Various options have been reported for the coverage of soft tissue defects on the ankle and heel area. Several proximally based vascular flaps from the foot have been developed for covering such defects. These flaps include the dorsalis pedis island flap, the medial and lateral plantar island flaps, the extensor digitorum brevis muscle flap, the flexor digitorum brevis muscle island pedicle flap, and the lateral calcaneal flap [6-9]. The lateral calcaneal artery flap, originally described by Grabb and Argenta [8] in 1981, is an axial-pattern fasciocutaneous flap that includes the lateral calcaneal artery, short saphenous vein, and the sural 


\section{Fig. 3. Case 3 (heel-pad defect, propeller flap)}

A 42-year-old man (patient 12) with a soft tissue defect of the heel pad, caused by a pressure sore (grade IV). (A) $5 \times 4 \mathrm{~cm}^{2}$ soft tissue defect, located in the area of the heel pad. $(B, C) A 6 \times 4 \mathrm{~cm}^{2}$ peroneal artery perforator-based pedicled flap was elevated for coverage of the defect. The propeller flap was rotated 160 degrees to cover the defect. The donor site was covered with a split-thickness skin graft. (D) When the patient visited the outpatient clinic five months after the operation, the flap and split-thickness skin graft were well taken.
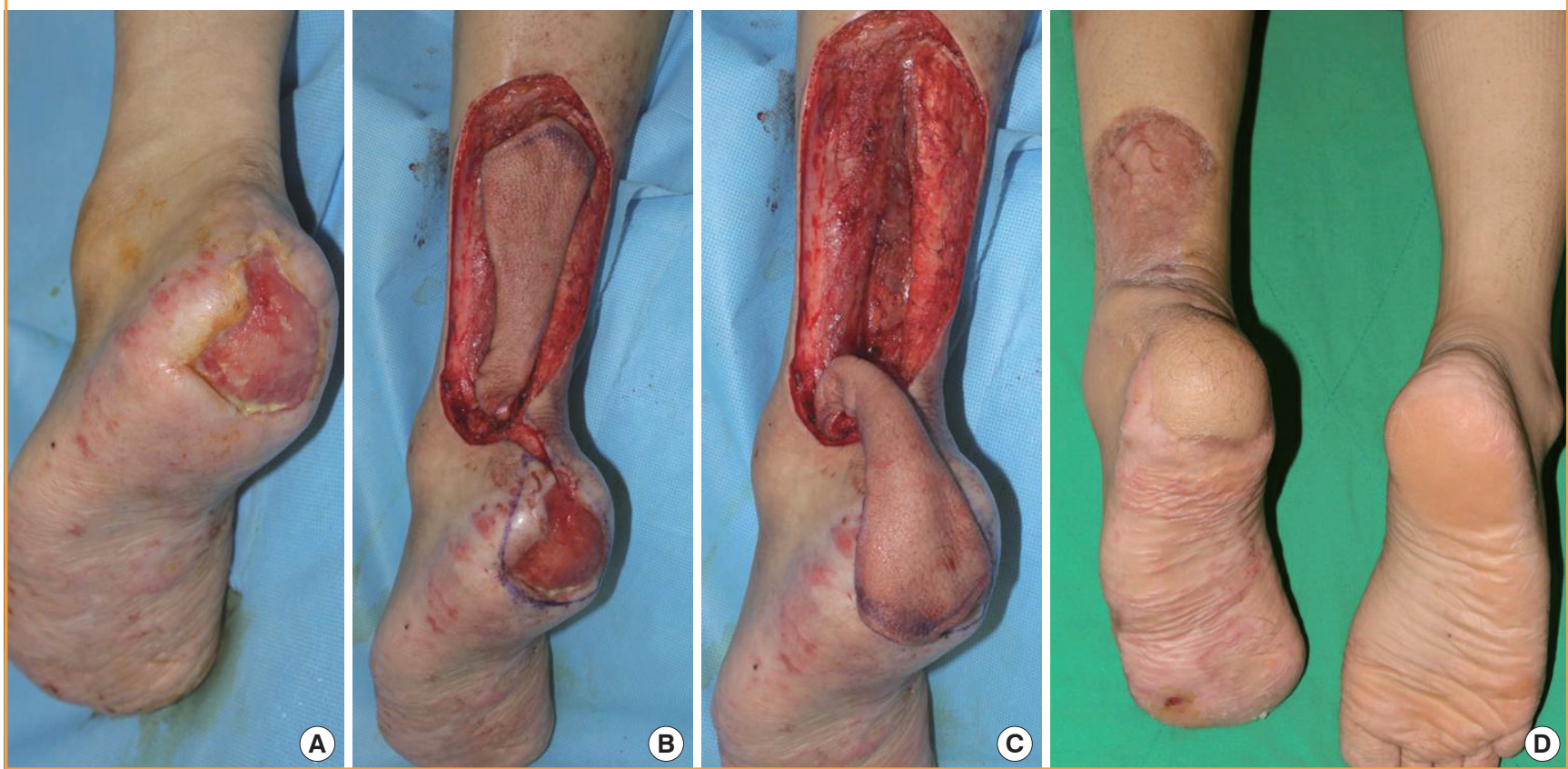

nerve. The disadvantage of this flap is donor site grafting over the periosteum, resulting in a depression deformity. Patients also experience sensory disturbances in the lateral part of the dorsum of the foot. Distally based flaps are also possible options for reconstruction of the heel pad. These flaps include the reverse anterior tibial flap and the reverse posterior tibial flap $[11,12]$. However, they require the sacrifice of an important leg artery and create obvious contour deformities at the donor site. The distally based sural neurocutaneous flap also has been used for ankle and heel pad reconstruction, since Masquelet and Romana [18] first introduced the distally based superficial sural neurocutaneous flap in 1990. Initially, some complications may be caused by designing the flap to be too large and making the pivot point too distal. The complications associated with this flap have been reported to include partial necrosis, wound dehiscence, hypo- or hyperesthesia such as paresthesia or numbness caused by damage to the sural nerve, and morbidity of the donor site. In order to avoid these complications, management of the pedicle in distally based neurocutaneous flaps has been performed. Several studies have proven the effectiveness of distally-based sural neurocutaneous flaps, which provide a constant blood supply as well as easy and quick elevation $[11,12,19]$.

Free flaps can be performed for reconstruction of the heel pad. An advantage of doing so is that the flap itself has good vascularity, and almost no limitation exists on its use regardless of its dis- tance from the defect site. The anterolateral thigh perforator free flap is an acceptable method for heel coverage. However, the peroneal artery perforator-based pedicled flap is a relatively easy and less time-consuming procedure in comparison with the anterolateral thigh perforator free flap, as it avoids the complexity, the multiple surgical sites, and the extra costs associated with free flaps and microsurgery.

Due to their well-described anatomy and vasculature, peroneal artery perforator-based pedicled flaps have been used for reconstructing ankle and heel defects. An anatomical study of fibular osteoseptocutaneous flaps showed that peroneal artery perforator-based pedicled flaps were more adaptable because they supplies a wider area and have a constant supply of arterial blood [20,21]. In 2003, Heitmann et al. [22] studied the vasculature of the peroneal artery, focusing on the perforator vessels. They dissected 20 fresh cadaver legs and identified a total of 95 cutaneous perforators of the peroneal artery greater than $0.3 \mathrm{~mm}$. The average number of cutaneous perforators was 4.8 (range, three to seven) per leg. The cutaneous perforators were either musculocutaneous (34\%) or septocutaneous (66\%). The musculocutaneous perforators were found predominantly in the upper thirds of the lower leg, while the septocutaneous perforators were located in the lower two thirds of the leg [22].

In this study, 12 patients underwent the reconstruction of softtissue defects of the ankle and heel using peroneal artery perfora- 
tor-based pedicled flaps. Both propeller flaps and peninsular flaps were used. Propeller flaps were used in 11 of the 12 cases. Lu et al. [12] recommended peninsular flaps as the first flap of choice for the reconstruction of the lower extremities. Reflecting the perforator-plus concept, the peninsular perforator flap has not only a dual arterial supply, from both the perforator itself and a random supply from its base, but also dual venous drainage. Moreover, the peninsular perforator flap is easy to elevate, and does not require the tedious dissection of the perforator. However, its rotation arc is limited by its base and is smaller than the rotation arc of the propeller flaps. In contrast, propeller flaps have the advantage of a high freedom of design and insetting. With the performance of tedious perforator dissection, propeller flaps could cover defects at any location in the lower extremities. Propeller flaps are more prone to venous congestion than peninsular flaps, but no venous congestion was found in our cases.

According to the anatomical study of Chang et al. [23] regarding the posterior malleolar space, two or three retromalleolar perforators are generally present, and one usually is larger than $0.5 \mathrm{~mm}$. We were able to find reliable perforators in this area by using a portable Doppler ultrasound. Compared to the distal pivot point of the reverse sural neurocutaneous flap, which was observed to be 4-7 $\mathrm{cm}$ above the tip of the lateral malleolus $[6,20]$, we were able to make the distal pivot point of the flap even more distal (1-3 cm above the tip of the lateral malleolus) using peroneal artery perforator-based pedicled flaps from the lateral retromalleolar area. For example, lowering the vascular pivot point of the flap by $1 \mathrm{~cm}$ results in the proximal donor site moving less than the usual $2 \mathrm{~cm}$ to the distal leg, thus reducing donor-site morbidity.

We usually repaired the donor site of the peroneal artery perforator-based pedicled flap with a skin graft, as the peroneal artery perforator-based pedicled flaps that we applied to the defects were somewhat large. This could be thought of as one disadvantage of using a peroneal artery perforator-based pedicled flap. However, the degree of donor-site morbidity is much less than the donor-site morbidity of reverse peroneal flaps or free flaps. Moreover, when patients underwent more than two months of follow-up, we observed acceptable functional and aesthetic results. Of the 12 patients, 10 achieved complete flap survival without major complications, although two patients experienced minor wound dehiscence. Nevertheless, both wounds healed after debridement and conservative management. No patients had any functional deficits of the lower extremities upon outpatient follow-up.

In this study, surgical nerve repair was not performed. The reinnervation of the flaps would have improved the sensory recovery of the reconstructed site. The average follow-up period of this study was 9.7 months, which was not long enough to assess nerve reinnervation. However, previous clinical studies have found that most flaps gained protective sensibility after 12 months, regardless of surgical nerve repair $[24,25]$.

The major limitation of this study is that it evaluated a small sample of patients. Further study is needed, with larger patient groups, in order to analyze the relationships between various comorbidities and clinical outcomes. However, we verified the effectiveness of peroneal artery perforator-based pedicled flaps for ankle and heel reconstruction in comparison to previously used methods. Peroneal artery perforator-based pedicled flaps are a reliable modality of ankle and heel reconstruction, and have the advantage of involving the movement of a relatively large fasciocutaneous flap with a reliable blood supply that is similar to the original tissue and does not require microvascular anastomosis. In addition, we used a perforator from the lateral retromalleolar area, thereby lowering the pivot point and reducing the donor-site morbidity.

\section{REFERENCES}

1. Lee YH, Rah SK, Choi SJ, et al. Distally based lateral supramalleolar adipofascial flap for reconstruction of the dorsum of the foot and ankle. Plast Reconstr Surg 2004;114:1478-85.

2. Jakubietz RG, Jakubietz DF, Gruenert JG, et al. Reconstruction of soft tissue defects of the Achilles tendon with rotation flaps, pedicled propeller flaps and free perforator flaps. Microsurgery 2010;30:608-13.

3. Terzic Z, Djordjevic B. Clinical aspects of reconstruction of the lower third of the leg with fasciocutaneous flap based on peroneal artery perforators. Vojnosanit Pregl 2014;71:39-45.

4. Rad AN, Singh NK, Rosson GD. Peroneal artery perforatorbased propeller flap reconstruction of the lateral distal lower extremity after tumor extirpation: case report and literature review. Microsurgery 2008;28:663-70.

5. Chang SM, Zhang K, Li HF, et al. Distally based sural fasciomyocutaneous flap: anatomic study and modified technique for complicated wounds of the lower third leg and weight bearing heel. Microsurgery 2009;29:205-13.

6. Hartrampf CR Jr, Scheflan M, Bostwick J 3rd. The flexor digitorum brevis muscle island pedicle flap: a new dimension in heel reconstruction. Plast Reconstr Surg 1980;66:264-70.

7. Morrison WA, Crabb DM, O'Brien BM, et al. The instep of the foot as a fasciocutaneous island and as a free flap for heel defects. Plast Reconstr Surg 1983;72:56-65.

8. Grabb WC, Argenta LC. The lateral calcaneal artery skin flap (the lateral calcaneal artery, lesser saphenous vein, and sural nerve skin flap). Plast Reconstr Surg 1981;68:723-30. 
9. Cai PH, Liu SH, Chai YM, et al. Free peroneal perforatorbased sural neurofasciocutaneous flaps for reconstruction of hand and forearm. Chin Med J (Engl) 2009; 122:1621-4.

10. Koshima I, Moriguchi T, Ohta S, et al. The vasculature and clinical application of the posterior tibial perforator-based flap. Plast Reconstr Surg 1992;90:643-9.

11. Ruan HJ, Cai PH, Schleich AR, et al. The extended peroneal artery perforator flap for lower extremity reconstruction. Ann Plast Surg 2010;64:451-7.

12. Lu TC, Lin CH, Lin CH, et al. Versatility of the pedicled peroneal artery perforator flaps for soft-tissue coverage of the lower leg and foot defects. J Plast Reconstr Aesthet Surg 2011; 64:386-93.

13. Ribuffo D, Atzeni M, Saba L, et al. Clinical study of peroneal artery perforators with computed tomographic angiography: implications for fibular flap harvest. Surg Radiol Anat 2010;32:329-34.

14. Zhang FH, Chang SM, Lin SQ, et al. Modified distally based sural neuro-veno-fasciocutaneous flap: anatomical study and clinical applications. Microsurgery 2005;25:543-50.

15. Akhtar S, Hameed A. Versatility of the sural fasciocutaneous flap in the coverage of lower third leg and hind foot defects. J Plast Reconstr Aesthet Surg 2006;59:839-45.

16. Morgan K, Brantigan CO, Field CJ, et al. Reverse sural artery flap for the reconstruction of chronic lower extremity wounds in high-risk patients. J Foot Ankle Surg 2006;45: 417-23.

17. Lee JH, Chung DW. Reverse lateral supramalleolar adipofas- cial flap and skin grafting for one-stage soft tissue reconstruction of foot and ankle joint. Microsurgery 2010;30:423-9.

18. Masquelet AC, Romana MC. The medialis pedis flap: a new fasciocutaneous flap. Plast Reconstr Surg 1990;85:765-72.

19. Park JS, Roh SG, Lee NH, et al. Versatility of the distallybased sural artery fasciocutaneous flap on the lower leg and foot in patients with chronic disease. Arch Plast Surg 2013; 40:220-5.

20. Chen YL, Zheng BG, Zhu JM, et al. Microsurgical anatomy of the lateral skin flap of the leg. Ann Plast Surg 1985;15:3138.

21. Wei FC, Chen HC, Chuang CC, et al. Fibular osteoseptocutaneous flap: anatomic study and clinical application. Plast Reconstr Surg 1986;78:191-200.

22. Heitmann C, Khan FN, Levin LS. Vasculature of the peroneal artery: an anatomic study focused on the perforator vessels. J Reconstr Microsurg 2003;19:157-62.

23. Chang SM, Zhang F, Xu DC, et al. Lateral retromalleolar perforator-based flap: anatomical study and preliminary clinical report for heel coverage. Plast Reconstr Surg 2007;120: 697-704.

24. Hong JP, Kim EK. Sole reconstruction using anterolateral thigh perforator free flaps. Plast Reconstr Surg 2007;119: 186-93.

25. Kuran I, Turgut G, Bas L, et al. Comparison between sensitive and nonsensitive free flaps in reconstruction of the heel and plantar area. Plast Reconstr Surg 2000;105:574-80. 